Original research article

\title{
Barriers and facilitators of breast self-examination among rural women of procreative age
}

\author{
Sasmita Das *, Sagarika Sahoo, Sefali Moharana \\ Siksha 'O' Anusandhan, Deemed to be University, SUM Nursing College, Department of Medical and Surgical Nursing, Bhubaneswar, Odisha, India
}

\begin{abstract}
Aim: This study aimed to assess the barriers and facilitators in practicing breast self-examination (BSE) in rural women of procreative age, for detecting breast cancer in a state of Eastern India.

Methods: Considering the medical significance of breast cancer in society, a quasi-experimental study was designed, where a pre-test and post-test was conducted with a self-structured questionnaire and checklist, to explore facilitators and barriers and the effect of BSE in these women. This study conveniently sampled the rural women within the procreative age group of 15 to 50 , according to selection criteria by trained nursing professionals. Initially, 553 women were selected in the study. However, only 502 of them were used for final analysis and the other 51 were excluded due to inadequate responses.

Results: After the one-month study period, the results of the post-test study were statistically extremely significant when compared to the pre-test results regarding the knowledge and steps of BSE. No significant association was found between barriers, the facilitator of BSE and other demographic factors.

Conclusions: This study concluded that BSE technique can be used by all rural women in the procreative age group - with the help of trained health care professionals and nurses - who can make them understand the importance of BSE in the detection of breast cancer.
\end{abstract}

Keywords: Barriers; Breast cancer; Breast self-examination; Facilitator

\section{Introduction}

The economic progress of India is largely dependent on good health, as healthy people have longer lives and make a larger contribution to a country's growth and economy. Several factors are responsible for the health status, and the government is largely responsible for providing the best quality health services to its citizens. Among various health complications, the dreaded disease of cancer remains at the top for non-communicable disease. Breast cancer is one of the common forms of cancer in women around the world, affecting nearly 1.7 million cases each year, as reported in 2012 (Breast Cancer India, 2012). This constitutes about $12 \%$ of all new cancer cases and $25 \%$ of all cancer in women. As per global health estimates, it has been found that in 2011 over half a million women worldwide died from breast cancer. As per a survey report from 2015, India contributes $17 \%$ of the total world population that suffer from breast cancer. In India, 1 in every 30 women develops breast cancer - according to the Indian Council of research Data (Breast Cancer India, 2012). Indian cancer society statistics revealed that almost 75,800 new breast cancer cases are detected each year, which makes it the number one dreadful disease in women. Annually the disease claims nearly 35,000 lives, and so experts have predicted that the incidence of breast cancer will double in the next 10 years, simultaneously increasing the mortality rates (Breast Cancer India, 2012). To combat this, many researchers, doctors, NGPs and social activists are working day and night. However, even after so many attempts, there are various social barriers that hinder the success of BSE and its outcome. Every human being is born with the responsibility to protect his or her own health. This responsibility cannot be carried out, if one is ignorant. Increasing the awareness of fellow human beings in the field of health is the moral responsibility of each health professional. This is only possible by educating the public (Chanu, 2011).

High levels of morbidity and mortality are associated with breast cancer, especially in developing countries, due to late detection. In India, various health professionals are trying to educate women from all communities to avoid late presentation. Clinical breast examination mammography and breast self-examination (BSE) are the most widely used methods for screening breast cancer (Armin et al., 2014; Avci and Kurt, 2008). Among the above techniques, BSE is considered as safe, effective, easy, private and as economical as the screening methods - involving no costs or requiring any specific equipment in the early detection of breast cancer. Although BSE alone is not sufficient for confirming cancer, it is still considered an essential screening method for its early diagnosis. The majority of respondents who practice BSE do not know what

\footnotetext{
* Author for correspondence: Sasmita Das, Siksha 'O' Anusandhan University, Deemed to be University, SUM Nursing College, Department of Medical and Surgical Nursing, K-8 Kalinga Nagar, 751003 Bhubaneswar, Odisha, India; e-mail: das.sasmita2@gmail.com http://doi.org/10.32725/kont.2019.002
}

Submitted: 2018-04-16 • Accepted: 2018-11-27 • Prepublished online: 2019-02-28

KONTAKT 21/1: 39-43 • EISSN 1804-7122 • ISSN 1212-4117

(c) 2019 The Authors. Published by University of South Bohemia in České Budějovice, Faculty of Health and Social Sciences.

This is an open access article under the CC BY-NC-ND license. 
to look for (Faronbi and Abolade, 2012). Women aged 20 years and older are recommended to perform breast self-examination (Obaji et al., 2013). Proper BSE techniques have clearly shown to be related to the ability to detect lumps, and it remains a useful part of breast cancer screening.

Many studies have been carried out to ascertain the facilitators and barriers that influence the use of BSE in women and (Gumus et al., 2010; Tarawneh and Al-Atiyyat, 2013). Various studies have revealed several barriers to BSE practice, which includes socio-demo-graphic factors, social and cultural concepts of breast cancer, information and awareness regarding breast cancer (Hisham and Yip, 2004; Rasu et al., 2011). The results of the present study will give an insight into the barriers and facilitators of breast self-examination to health professionals and raise awareness about early detection of breast cancer among women of procreative age groups in a state of eastern India. Hence the findings from this study will provide a platform for women to raise community self-awareness and awareness about breast cancer and the role of BSE - especially in India, where socio-economic hindrance is a major issue.

\section{Materials and methods}

\section{Study design}

The present study was designed as quasi-experimental, where one pre-test group and another post-test group were designed with a self-structured questionnaire and checklist in order to explore facilitators and barriers and the effect of BSE on rural woman of procreative age. The duration of the study was one month, and trained nursing professionals carried it out.

\section{Samples and data collection}

This study conveniently sampled the rural women within the procreative age group of 15 to 50, according to selection criteria by trained nursing professionals. Subjects suffering from any of the following clinical conditions: pregnancy, cancer and mental disorders were excluded. The data was collected during the period 1st February to 2nd March 2018. Initially, 553 women were selected in the study, however, 502 of them were used for final analysis and the remaining 51 were excluded due to inadequate responses. To affirm the statistical significance of our sample size, the formula $N=\left(Z^{2} \times P \times P\right) / e^{2}$ was used. The study was approved by the Institutional Ethical and Review Board. Nurses trained in BSE techniques were appointed to conduct the study. Written informed consent was collected - if the subject agreed to participate in the study after a detailed explanation of the objectives and methodology of the study. They were also informed that they could give up at any time during data collection. The collected data were kept confidential to protect privacy and the rights of the participants.

\section{Description of tools}

A self-structured questionnaire and checklist were prepared in five sections: Section $A$ dealt with 11 items related to the socio-demographic information of the participants. Section $B$ (pre and post-test) dealt with a self-structured multiple-choice questionnaire for assessing knowledge of women in the procreative age group regarding breast self-examination. Section $C$ (pre and post-test) assessed the observational checklist for assessing skill in BSE among the women within the procreative age group. Section $D$ dealt with the structured questionnaire regarding the facilitator of breast self-examination and this section is comprised of five statements. Section $E$ dealt with the structured questionnaire regarding barriers of BSE and this section is comprised of four statements. Intervention used for knowledge and skill in BSE were a planned teaching program for knowledge along with teaching different steps of BSE technique to assess skill.

\section{Data analysis}

Frequency and percentage were used for analyzing demographic data, knowledge and methods of BSE. Furthermore, to analyze the level of difference in knowledge and methods of BSE between the pre-test and post-test score of the selected samples, $t$-test was used. The association between facilitator and barrier with selected demographic variables among women was calculated by chi-square test.

\section{Results}

It was observed that $58 \%$ of the subjects were in the group of $15-30$ years, $36 \%$ were in the group of $31-45$ years and $6 \%$ were in the 46-50 years age group. Concerning educational qualification, this study showed that $30 \%$ of subjects were illiterate, and $66 \%$ and $4 \%$ had completed their primary and secondary education respectively. $88 \%$ of the subjects were married, $8 \%$ were single and $4 \%$ were widowed. In terms of occupation, $82 \%$ were homemakers, $10 \%$ were workers and $8 \%$ were students. Regarding general information on BSE, $68 \%$ of the sample had no idea, and $32 \%$ had some idea regarding BSE.

The analysis of the data revealed that none of the women had any accurate knowledge regarding BSE in pre-test analysis. However, after intervention in post-test, $88 \%$ of the women had gathered accurate knowledge regarding BSE, and $12 \%$ had average knowledge. The current analysis shows that all subjects have poor skills in BSE, and none of the subjects in the pre-test has good or average skills. However, after intervention in the post-test, $96 \%$ of subjects had good skills in breast self-examination, $4 \%$ had average skills and none had poor skills in BSE.

A paired $t$ test value of 36.46 was obtained for post-test scores regarding knowledge regarding BSE, whereas in the skills step a value of 40.18 was obtained. The $p$ value was more than the tabulated value at 0.05 , which is extremely significant in comparison to the pre-test results. There was significant increase in the pre-test level of knowledge and skill of breast self-examination after the intervention in post-test among the rural women in procreative age group (Table 1).

The current analysis of the data recorded that the false belief of not suffering from breast cancer in the future was a major barrier (ranked 1st) for not practicing BSE (as $72.11 \%$ women had this belief). In 2nd position was the item "I don't know about BSE", as 67.9\% (341) of the sample agreed with it. The item ranked third was: "I don't have enough privacy to do BSE", as $57.56 \%$ (289) of the sample agreed with it (Table 2).

It was observed that getting information regarding BSE from TV/Radio at home is highly beneficial; it has the highest score andranks 1st, as $94.2 \%$ agreed with this statement. Similarly, the training and awareness program on BSE was ranked as 2 nd as 161 (32.1\%) of the women agreed to this statement). In third position was the statement: "I know at least one diagnostic method to detect breast cancer", as 145 (28.9\%) of the sample agreed with this statement (Table 3).

Significant association was not found between barriers and facilitators of BSE with age, education, occupation, and marital status, source of information and performance for BSE, and family background of breast cancer. 
Table 1. Paired $t$-test for pre-test and post-test knowledge and skill in breast self-examination among women in reproductive age group

Pre-test and post-test of breast self-examination

\begin{tabular}{|c|c|c|c|c|c|c|}
\hline Item & Mean & $S d$ & Paired $t$-test & Df & $P$ value & Inference \\
\hline Pre-test knowledge & 0 & 0 & \multirow{2}{*}{36.46} & \multirow{2}{*}{49} & \multirow{2}{*}{$<0.0001$} & \multirow{2}{*}{ Extremely significant } \\
\hline Post-test knowledge & 4.4 & 0.86 & & & & \\
\hline Pre-test skill in steps of BSE & 0 & 0 & \multirow{2}{*}{40.18} & \multirow{2}{*}{49} & \multirow{2}{*}{$<0.0001$} & \multirow{2}{*}{ Extremely significan } \\
\hline Post-test skill in steps of BSE & 8.3 & 1.46 & & & & \\
\hline
\end{tabular}

Table 2. Ranking of the barriers to breast self-examination

\begin{tabular}{|c|c|c|c|c|}
\hline Sl. No. & Item statement & Total score & $\%(n=502)$ & Rank \\
\hline 1 & False belief of never having breast cancer in the future & 362 & $72.11 \%$ & 1st \\
\hline 2 & Not knowing about BSE & 341 & $67.90 \%$ & 2nd \\
\hline 3 & Not having enough privacy to do BSE & 289 & $57.56 \%$ & $3 r d$ \\
\hline 4 & Not believing in the efficacy of this BSE test & 186 & $37.10 \%$ & 4 th \\
\hline 5 & BSE is not important & 176 & $35.05 \%$ & 5 th \\
\hline
\end{tabular}

Table 3. Ranking of the facilitators of breast self-examination

\begin{tabular}{llccc} 
Item no. & Statement & Total score & \% $(n=502)$ & Rank \\
\hline 1 & $\begin{array}{l}\text { TV/Radio at home is beneficial for learning breast self- } \\
\text { examination }\end{array}$ & 471 & $94.20 \%$ & \\
2 & $\begin{array}{l}\text { Previous training or awareness on breast self-examination } \\
\text { (health professional, social workers) }\end{array}$ & 161 & $32.10 \%$ & 2 st \\
3 & Know at least one diagnostic method to detect breast cancer & 145 & $28.90 \%$ & $3 \mathrm{rd}$ \\
4 & History of breast cancer in families or relatives & 32 & $6.37 \%$ & 4 th \\
\hline
\end{tabular}

\section{Discussion}

The American Cancer Society has recommended a revised regimen for the diagnosis of breast cancer in compliance with breast cancer screening guidelines. This includes BSE, mammograms and clinical breast examinations - which have been linked to several barriers and facilitators. Health-care professionals who implement such intervention programs are instructed to explore and bring into the open these common barriers and facilitators to maximize working women's compliance with breast screening guidelines. Such programs are essential for early detection of breast cancer and to spread awareness (Kurtz et al., 1993). This study aimed to evaluate the practice, barriers and facilitators of BSE and its correlated factors with a prime focus on rural women. Treatment cost and mortality rate will be significantly lower if breast cancer is detected early. Hence it is essential to identify and address the factors affecting breast cancer diagnosis (Suleiman, 2014). The current study revealed that all subjects have a poor idea regarding the steps of BSE and none of the subjects have a good or average idea in the pre-test. After intervention in the post-test, $96 \%$ of subjects have a good idea regarding the steps of BSE, $4 \%$ of subjects have an average idea and none of the subjects have a poor idea regarding BSE. In a similar study, Hacihasanoğlu and Gözüm (2008) revealed that the rate of correct answers increased to $79.1-96.7 \%$ after training had been given to the subject; where pre-test it was 13.2-68.1\%.
The present study revealed that $57.56 \%$ of the rural women agreed to "not having enough privacy to do BSE", which is recorded as a major barrier; $67.9 \%$ of the women agreed to "not knowing about BSE"; $37.1 \%$ agreed to "I don't believe in the efficacy of that test"; $72.11 \%$ agreed to "thinking I can never have breast cancer", and $35.05 \%$ agreed to "it is not so important". These factors are the major barriers to the successful implementation of BSE. Al-Dubai conducted a similar study regarding barriers of BSE and found that $81.1 \%$ subjects had good information on breast cancer and $55 \%$ of them were practicing BSE. They also reported that of the $45 \%$ of subjects who never practiced BSE, $79.8 \%$ did not know how to do it, and the rest were apprehensive about having breast cancer, and many found it embarrassing or unpleasant. Reasons such as not touching their body, false positive results and insignificance of BSE were also reported (Al-Dubai et al., 2012; Norman and Brain, 2005). With respect to the barriers of practicing BSE amongst women, the lack of knowledge, being afraid of the diagnosis, not having symptoms, lack of family support and fear of detection of breast cancer were the main barriers to not practicing BSE (Al-Naggar et al., 2011; Rosmawati, 2010). Most women believed that BSE is not an accurate way of detecting cancer. The belief of "not touching their body" is a major barrier in relation to BSE. The findings of this study explore many aspects of prevention, orientation and perception towards BSE. Finally, a woman feels that BSE is a time-consuming process and most rural women complain about a lack of privacy for practicing it. One of the major facilitators of 
the study was the spread of information on and awareness of BSE through TV/Radio programs by different health professional and social workers. Most women preferred to get the information about BSE via leaflets, pamphlets and brochures. From this study, the message to society is that to prevent the spreading of breast cancer and breast diseases, nurses must take initiative in the discussed field and should be agents of change. Nurses will play a major role in providing health education and motivating women for creating awareness of BSE among rural women.

A study in Turkey was completed with elderly women's experiences with BSE, clinical breast examination and mammography screening, based on the same model. Data was collected through an interview guide based on the health belief model and the health promotion model, which revealed that barriers to screening were: insufficient knowledge, fear, neglect/postponement, embarrassment/religious beliefs, inability to make an appointment, lack of a physician's recommendation and health professionals' attitudes. Facilitating factors were: being informed about screening, fear, awareness of cancer screening, familial history of breast cancer and social support, making an appointment, health professionals' communication and physicians' recommendations (Kissal and Beşer, 2011). Another report from Turkey, which included 39 migrant women, attempted to identify correlation between BSE, clinical breast examination, and mammography using the same model resulted in 3 major reasons: (a) knowledge and awareness about breast cancer, (b) personal factors and (c) medical service provider and social environment. Lack of information, indifference, and cultural factors are the most important barriers to women (Tuzcu and Bahar, 2015). Our study also had the same set of barriers.

\section{Limitations of study}

Since the sample was rural women of procreative age, the findings cannot be generalized to the whole population in India.

\section{Conclusions}

After the careful interventions carried out by the nurses during this one-month study, it was noted that there was a need for adequate knowledge and skill with respect to BSE among women within the procreative age group. It was found that by using standardized BSE steps provided by breast cancer organizations, the knowledge and skill regarding this technique could be improved. Nurses must be aware of the facilitators and barriers in BSE and tactfully handle them for the benefit of women. Highly trained nursing administrators or educators with a well-planned implementation policy for BSE will help in early diagnosis and the prevention of breast cancer in rural women.

\section{Ethical approval}

The Institutional Ethical Committee approved this study, and prior consent of patients was obtained before it was conducted.

\section{Conflict of interests}

The authors have no conflict of interests to declare.

\section{Acknowledgements}

The authors appreciate the people who participated in this study, as well as the staff of SNC who helped in its successful completion. The authors are also thankful to Dr. Shakti Rath, Assistant Professor (Research), Faculty of Dental Sciences and Nursing, Siksha 'O' Anusandhan, for critically reviewing and preparing the manuscript.

\section{Bariéry a facilitátory samovyšetření prsů u žen na venkově v prokreativním věku}

\section{Souhrn}

Cíl: Cílem této studie bylo posoudit překážky a facilitátory v provádění samovyšetření prsů (BSE) u venkovských žen v prokreativním věku, za účelem zjištění rakoviny prsu ve východní Indii.

Metodika: Vzhledem k lékařskému významu rakoviny prsu ve společnosti byla navržena kvaziexperimentální studie, ve které byl proveden předběžný a následný test s vlastním dotazníkem a kontrolním seznamem, prozkoumání facilitátorů a bariér a vlivu BSE u těchto žen. Vzorkem byly venkovské ženy ve věkové skupině 15 až 50 let, které byly vybrány podle výběrových kritérií vyškolených ošetřovatelů. Zpočátku bylo ve studii zařazeno 553 žen, avšak pouze 502 z nich bylo použito k závěrečné analýze a dalších 51 bylo vyloučeno $\mathrm{z}$ důvodu nedostatečné odpovědi.

Výsledky: Po období jednoho měsíce byly výsledky posttestové studie statisticky nesmírně významné ve srovnání s výsledky předtestů ohledně znalostí a kroků BSE. Nebyla nalezena žádná významná asociace mezi bariérami, facilitátorem BSE a dalšími demografickými faktory.

Závěr: Tato studie dospěla k závěru, že technika BSE může být využita všemi venkovskými ženami v prokreativní věkové skupině - s pomocí vyškolených zdravotnických pracovníků a zdravotních sester - kteří jim mohou pomoci porozumět významu BSE při detekci rakoviny prsu.

Klíčová slova: bariéry; facilitátor; rakovina prsu; samovyšetření prsu 


\section{References}

1. Al-Dubai SA, Ganasegeran K, Alabsi AM, Abdul Manaf MR, Ijaz S, Kassim S (2012). Exploration of Barriers to Breast-Self Examination among Urban Women in Shah Alam, Malaysia: A Cross Sectional Study. Asian Pac J Cancer Prev 13(4): 1627-1632.

2. Al-Naggar RA, Al-Naggar DH, Bobryshev YV, Chen R, Assabri A (2011). Practice and barriers toward breast self-examination among young Malaysian women. Asian Pac J Cancer Prev 12(5): 1173-1178.

3. Armin J, Torres CH, Vivian J, Shaw SJ, Vergara C (2014). Breast self-examination beliefs and practices, ethnicity and health literacy: Implications for health education to reduce disparities. Health Educ J 73(3): 274-284. DOI: $10.1177 / 0017896912471048$.

4. Avci IA, Kurt H (2008). Health benefits and mammography rates of Turkish women living in rural areas. J Nurs Scholarsh 40(2): 170-75. DOI: 10.1111/j.1547-5069.2008.00222.x.

5. Breast Cancer India (2012). Statistics of breast cancer in India (global comparison). [online] [cit. 2019-04-21]. Available from: www.brestcance india.net/statistics/stat_global.html

6. Chanu SL (2011). A study to compare the knowledge regarding the Breast self-examination among rural and urban women at procreative age in selected rural and urban areas at Bangalore with a view to develop an information booklet. Rajiv Gandhi University. [online] [cit. 2019-04-21]. Available from: www. rguhs.ac.in/cdc/onlinecdc/uploads/05_N236_31918.doc

7. Faronbi JO, Abolade J (2012). Breast self-examination practices among female secondary school teachers in a rural community in Oyo State, Nigeria. Open J Nursing 2(2): 111-115. DOI: 10.4236/ojn.2012.22017.

8. Gumus AB, Cam O, Malak AT (2010). Socio-demographic factors and the practice of breast self-examination and mammography by Turkish women. Asian Pac J Cancer Prev 11(1): 57-60.

9. Hacihasanoğlu R, Gözüm S (2008). The effect of training on the knowledge levels and beliefs regarding breast self-examination on woman attending a public education centre. Eur J Oncol Nurs 12(1): 58-64. DOI: 10.1016/j.ejon.2007.06.005.

10. Hisham AN, Yip CH (2004). Overview of breast cancer in Malaysian women: a problem with late diagnosis. Asian J Surg 27(2): 130-133. DOI: 10.1016/S1015-9584(09)60326-2.

11. Kissal A, Beşer A (2011). Knowledge, facilitators and perceived barriers for early detection of breast cancer among elderly Turkish women. Asian Pac J Cancer Prev 12: 975-984.

12. Kurtz ME, Given B, Given CW, Kurtz JC (1993). Relationships of barriers and facilitators to breast self-examination, mammography, and clinical breast examination in a worksite population. Cancer Nurs 16(4): 251-259. DOI: 10.1097/00002820-199308000-00001.

13. Norman P, Brain K (2005). An application of an extended health belief model to the prediction of breast self-examination among women with a family history of breast cancer. Br J Health Psychol 10(1): 1-16. DOI: 10.1348/135910704X24752.

14. Obaji N, Elom H, Agwu U, Nwigwe C, Ezeonu P, Umeora O (2013). Awareness and practice of breast self-examination among market women in Abakaliki, South East Nigeria. Ann Med Health Sci Res 3(1): 7-12. DOI: 10.4103/21419248.109457.

15. Rasu RS, Rianon NJ, Shahidullah SM, Faisel AJ, Selwyn BJ (2011). Effect of educational level on knowledge and use of breast cancer screening practices in Bangladeshi women. Health Care Women Int 32(3): 177-189. DOI: 10.1080/07399332.2010.529213.

16. Rosmawati NH (2010). The usage and knowledge of mammography among women in sub-urban area in Terengganu, Malaysia. Asian Pac J Cancer Prev 11(3): 767-771.

17. Suleiman AK (2014). Awareness and attitudes regarding breast cancer and breast self-examination among female Jordanian students. J Basic Clin Pharm 5(3): 74-78. DOI: 10.4103/09760105.139730.

18. Tarawneh E, AI-Atiyyat N (2013). Exploration of barriers to breast self-examination and awareness: A review. Middle East J Nursing 6(7): 1-6. DOI: 10.5742/MEJN.2013.76333.

19. Tuzcu A, Bahar Z (2015). Barriers and facilitators to breast cancer screening among migrant women within Turkey. J Transcult Nurs 26(1): 47-56. DOI: $10.1177 / 1043659614526245$. 